\title{
As others see us
}

\author{
M. E. Richardson, '
}

\section{Another instalment from the literary archives focuses on the public image of dentists and dentistry. The feedback is not exactly flattering.}

\begin{abstract}
A with the world it takes all sorts to exception.

\section{The pleb}

In the early years of the twentieth century, before the post-war social revolution, to be a dentist was regarded as the equivalent of being 'in trade'. In the words of Naomi Mitchison:' 'Of course no dentist was a gentleman and one could never meet one socially.'

These sentiments were echoed by others, notably C S Lewis:2 'I seem to see clearly now, what all his whipping boys had in common. They were the boys who fell below a certain social status, the boys with vulgar accents. Poor P. - dear, honest, hard-working, friendly, healthily pious $P$. - was flogged incessantly, I now think, for one offence only; he was the son of a dentist.' and Cyril Connolly: 'It was the hot summer of 1910 and we wore dark blue cockades for the general election, except the dentist's son, who was a liberal. He seemed to me to smell quite different from other boys. Oily'.
\end{abstract}

\section{The drudge}

Paul Bowles presented dentistry as a second choice, second rate, dead end occupation. ${ }^{4}$ 'My father had hoped to be a concert violinist, but expectedly his parents, considering this a highly impractible ambition, vetoed it with energy, whereupon he retaliated by having a nervous breakdown. His older brother was already studying dentistry, a fact doubtless instrumental in persuading him, once he was over his tantrum, to follow suit. He married at thirty, and I was born a little more than two years later, his only offspring. Until I was five, he was busy building up his practice; and after

$1^{*}$ Associate Specialist Orthodontist (retired), 33 Cherryvalley Park, Belfast BT5 6PN,

N Ireland

${ }^{*}$ Correspondence to: Margaret Richardson REFEREED PAPER

Received 28.02.00; Accepted 06.03.00

(C) British Dental Journal 2000; 189: 290-294 that he always seemed to have too many patients.'

\section{The bore}

Margaret Atwood highlighted the tedium attached to dentistry, at least in the minds of her female characters. 'When I went out to the kitchen to get breakfast Ainsley was there, moping: she said she had been to a bad party the night before. She swore there had been nothing but dentistry students, which depressed her so much she had consoled herself by getting drunk.

"You have no idea how soggy it is," she said, "having to go through twenty conversations about the inside of peoples' mouths.

The most reaction I got out of them was when I described an abscess I once had. They positively drooled. And most men look at something besides your teeth, for god's sake.................

"As if I didn't get enough of that at work," she said. Ainsley has a job as a tester of defective electric toothbrushes for an electric toothbrush company......... "It's an absolute fixation. I expect they all carry those bent mirrors around in their coat pockets and peer into their own mouths every time they go to the john to make sure they're still cavity free." ... "Could you imagine kissing one? He'd say 'open wide' beforehand. They're so bloody one-track.". ."Oh god," said Ainsley, "I can't face it. Another day of machines and mouths. I haven't had an interesting one since last month, when that lady sent back her

\section{In brief}

- This paper offers a change of subject from clinical and academic dentistry.

- It presents a salutary and entertaining look at the profession from the patient's viewpoint.

- Lesson may be learned about the dentists-patient relationship. toothbrush because the bristles were falling off. We found out she'd been using Ajax.”'

\section{The butt}

Agatha Christie depicted the dentist as a figure of fun. ${ }^{6}$

"I say, you don't mind my being a dentist, do you?"

Jane raised her eyebrows.

"I? Mind?"

"What I mean is, there's always something rather - well, comic about a dentist. Somehow it's not a romantic profession. Now a doctor everyone takes seriously."

"Cheer up," said Jane. "A dentist is decidedly a cut above a hairdresser's assistant."'

\section{The sadist}

Few dentists have a truly sadistic streak it just seems that way to their patients. Perhaps that is not altogether surprising in the days before good anaesthesia and the high speed drill.

Rosamund Lehman quoted an old Scots gillie's definition of a dentist: ' 'Once as I drive beside him on the box of the high dog cart with Yankee the big chestnut between the shafts, he tells me what a dentist is. "A dentist is a man who airrns his daily bread from the cries of strong men, the moans of weak women, and the shrieks of little tenderr children."'

In her autobiography Cynthia Asquith wrote: ${ }^{8}$ '.........but I never came to London between the end of July and the following May unless for an odd night or two to have my teeth seen to, then an excruciating ordeal that punctuated the year of every welllooked-after child. In those days, I think a dentist must have been esteemed in direct ratio to the amount of pain he inflicted. Mine had a great reputation. I have but to see a bound volume of Punch to be back in an agony of anticipation in his waitingroom.' And Julian Greene graphically described his experiences at the hands of a positive monster!' 'I have said very little about my Irish godmother, Agnes Farley. She had married an American dentist who looked like Julius Caesar, and whom we thought mad. He occasionally turned prophet, was of the opinion that all the Latin races should be wiped out, called the Bible " $a$ fool book", admired the Kaiser, etc, etc. All that was Farley, and no one paid much 
attention. He was small, slim, calm, and precise, given to violent fits of anger, fanatical anger, for there was a religious strain in him. One day, in the course of a discussion in which he tried a woman friend's patience to the breaking point, the latter, choking with rage, put a curse on him in a loud voice. Whereupon he caught her by the neck and while telling her he was acting for the good of her soul, tightened his grip, stifled and shook her until, not wishing to die on the spot, she took the curse back. As for us, for other reasons and by other means, he excelled at making us cry. To go to him, sit in his frightful black leather armchair, was more than any one of us could bear. Our parent's authority became necessary and the operation took place amid tears and screams. For he belonged to the old school, the one that hurt the patient on principle. He announced the torture in a calm voice, prepared his drill with finical care. Beads of perspiration stood on our brows and for my part, I sometimes drooled with horror. "Open wider!" How well we knew that sentence. It was in itself alone a nightmare. Terrible moans followed almost immediately, long, useless shrieks. "I'm sorry, child," said Farley in a blank voice and the drill went zzzzzzzzzzzzzz. The torment over, this mysterious man would wipe our face with his handkerchief. He was fond of children, felt for his victims a compassion more awful than his cruelty. In other times he would have made a wonderful torturer. Maybe he did not know it. I have a charming letter he wrote me in 1912. It does not wipe out the memory of minutes of what might be called exquisite pain. Why did we have to go to him? On account of Agnes. Mamma said: "All dentists hurt. Farely is no worse than the others. So that's that."............... Near the door was a bust of Napoleon as a Roman emperor. Often, as though by chance, Farely stood by the Ceasarean head and sometimes there was someone to cry out: "Oh! Why ...Oh! It's extraordinary! Mr. Farley, have you ever been told you looked like Napoleon Bonaparte?" He smiled modestly and then returned to his victims. Entreaties and screams followed swiftly. One day I bit him and he slapped me. He had thrust a finger into my mouth, in search of some sensitive spot or other, and my jaws closed as hard as they could over one of his knuckles. I do not regret it, I avenged a whole lot of people.'

Another famous novelist, Henry James, found some compensation for the prospective torture occasioned by a visit to his dentist. 10 'Broadway was the feature and the artery, the joy and the adventure of one's childhood, and it stretched, and prodigiously, from Union Square to Barnum's great American Museum by the City Hall or only went further on the Saturday mornings (absurdly and deplorably frequent, alas) when we were swept off by a loving aunt, our mother's only sister, then much domesticated with us and to whom the ruthless care had assigned itself from the first, to Wall Street and the torture chamber of Dr. Parkhurst, our tremendously respectable dentist, who was so old and so empurpled and so polite, in his stock and dress-coat and dark and glossy wig, that he had been our mother's and our aunt's haunting fear in their youth as well, since in their quiet Warren Street, not far off, they were, dreadful to think, comparatively under his thumb. He extremely resembles, to my mind's eye, certain figures in Phiz's illustrations to Dickens, and it was clear to us through our long ordeal that our elders must, by some mistaken law of compensation, some refinement of the vindictive, to be making us "pay" for what they in like helplessness had suffered from him: as if we had done them any harm! Our analysis was muddled, yet in a manner relieving, and for us too there were compensations, which we grudged indeed to allow, but which I could easily, even if shyly, have named. One of these was Godey's Lady's Book, a sallow pile of which (it shows to me for sallow in the warmer and less stony light of the Wall Street of those days and through the smell of ancient anodynes) lay on Joey Bagstock's table for our beguilement while we waited: I was to encounter in Phiz's Dombey and Son that design for our tormentor's type. There is no doubt whatever that I succumbed to the spell of Godey, who, unlike the present essences, was an anodyne before the fact as well as after; since I remember poring, in his pages, over tales of fashionable life in Philadelphia while awaiting my turn in the chair, not less than doing so when my turn was over and to the music of my brother's groans.'

\section{The lush}

Frances Partridge told a story attributed to her friend Alix Stratchey:11 "'I've been having tooth trouble and didn't want to go to London, but I found a sort of defrocked dentist in Marlow, who visited people in their houses with a plug-in drill. It made a horrible noise and worked anything but smoothly, and the tooth he mended soon fell to bits. It must come out, he said, and I have to drive and bring him back to Lord's Wood where he gave me an injection and then found he'd left his forceps behind, so I had to drive him to Marlow again with a frozen gum to get them. When he got to work the gum was rapidly unfreezing, and James and my mother, eating their dinner in the room below were electrified to hear wild yells and the sound of me being dragged round the room in a basket chair." It turned out he was a drunkard who had lost his practice thereby.'

\section{The socialite}

Despite the reservations expressed by Naomi Micheson ${ }^{1}$ some members of the profession move in higher social circles. Diana Cooper's dentist was not averse to advertising the fact. ${ }^{12}$ 'To Bath, where I saw Mr Miller, my dentist, who did not fail to show me the tiepin given to him by the Duke of Connaught and the coloured photograph of the orchids sent him by Queen Mary. I thought it (the orchids) an unusual present from a queen to a dentist.' And Gwen Raverat's mother almost deified their dentist: ${ }^{13}$ 'Our mother was always faithful to Our Doctor, who was the only good doctor in the world. His lightest word was enshrined like a fly in amber, and remained a gospel truth for ever and ever; and as for Our Dentist, in London, he was practically a god....

Dora Carrington's dentist fraternized with the artistic set. ${ }^{14}$ 'Darling Lytton, Had a curious dinner with $\mathrm{Mr}$ Tressiller dentist of Falmouth last night. He was a great friend of Tuke. But not at all what you might imagine from that. He gave one a curious vision of Falmouth life. He was a great admirer of Warnford who dominates low life in that port, in very much the same way as Augustus does in 
Chelsea. But he was one of those characters who perpetually surprise one by the great originality and equal stupidity of their remarks. I think if he was a food he would be beefsteak'

\section{The snob}

This dentist condescends to those whom he considers to be his social inferiors as in Joyce Cary's novel 'Herself Surprised'. 15 'But the dentist gave me no comfort. I did not deserve it, perhaps, with the life I led; but it was a terrible blow to be told that the child had been neglected. She should have had a plate, he said - two of her front teeth had been killed.

It was no good me telling him that we had gone to the best dentist in Bradnall. He looked into the air over me and pressed his lips together as if I were not fit to speak to. He would make me no promise even to save her front teeth.

I could see he was the kind of man who thought women were fools to think so much of looks, and I was in terror that he would pull out Nancy's front teeth only to triumph over me. I could not even be nice to him in case he thought that I was trying to charm him. He was the kind of man who would have turned spiteful to a charmer, and even as it was he kept looking down my figure and my dress as if to say: "a common cheap woman who might as well be on the streets."

Yet I had put on my best dress and powdered to please him, not knowing that a London dentist was almost the same thing as a doctor or a clergyman and that I ought to have dressed down for him, instead of up.'

\section{The philosopher}

Intellectual qualities were attributed to the profession by John Cowper Powys: ${ }^{16}$ And Dr. Schott suited me down to the ground in another peculiarity. He combined scepticism of everything with credulity about everything, and I am convinced this is the true Shakespearian way wherewith to take life. Incidentally he was a first rate dentist, and I would like to ask you, the reader, why do many real philosophers become dentists? Dr. Schott is a dentist still, on Mission Street in San Francisco. Happy, yea! thrice happy are those who sit in that chair of philosophical novocaine.

\section{The idealist}

This dentist delights in devising grandiose schemes for oral rehabilitation not always appreciated by the recipient. Mr Quilty in Nabakov's 'Lolita' is a good example. ${ }^{17}$

'I told Dr Quilty that, in hope of alleviating facial neuralgia, I had decided to have all my teeth removed. What would a complete set of dentures cost? How long would the process take, assuming we fixed our first appointment for some time in November?

A white-smocked, grey-haired man, with a crew cut and the big flat cheeks of a politician, Dr Quilty perched on the corner of his desk, one foot dreamily and seductively rocking as he launched on a glorious long-term plan. He would first provide me with provisional plates until the gums settled. Then he would make me a permanent set. He would like to have a look at that mouth of mine. He wore perforated pied shoes. ..... His foot rocked, his gaze was inspired. It would cost me around six hundred. He suggested he take measurements right away, and make the first set before starting operations. My mouth to him was a splendid cave full of priceless treasures, but I denied him entrance.

"No," I said. "On second thoughts, I shall have it all done by Dr Molnar. His price is higher, but he is of course a much better dentist than you."

I do not know if any of my readers will ever have a chance to say that. It is a delicious dream feeling. Clare's uncle remained sitting on the desk, still looking dreamy, but his foot had stopped push-rocking the cradle of rosy anticipation. On the other hand, his nurse, a skeleton thin, faded girl, with the tragic eyes of unsuccessful blondes, rushed after me so as to be able to slam the door in my wake.'

William Sayoran could not cope with the elaborate treatment plan proposed by his enthusiastic dentist: 18 'I had a Beverly Hills dentist once who was a nut about the importance of flawless occlusion and all the rest of the stuff dentists deal in - inlays, caps, bridges, partials, impartials, pontoons, catamarans. There was only one religion in the world as far as he was concerned - teeth. And like most dentists he had very good teeth. By nature he had them, whereas by nature I had poor teeth.

One day it was necessary at last to say,
"Doc, teeth are very important, I know, for chewing food, for talking, and for flashing smiles, but staying alive is also important, and this prolonged dentistry is killing me. I've been coming and going for a year, my jaws hurt, my gums hurt, the teeth with inlays in them don't feel right, and when I first started here the theory was that you would do everything I needed in under six weeks, two visits a week. Now, I know you're doing beautiful work, because you've told me so, but this is a form of beauty I can't really use. I want my mouth to begin to feel free again, and for a year it has felt caught and tortured, and not really my mouth, but yours. It isn't going to do at all for you to get a perfect reconstruction job in there, and then to go to my funeral." He said I was an awful kidder, but I finally had to quit and let my mouth go back to being mine - no bridges, no nothing.'

\section{The lover}

Laurie Lee described a unique form of courtship with an unusual token of affection. ${ }^{19}$ 'All the nieces were screechingly gay, except for the beautiful Lola, whose boyfriend, a dentist, was late. This boy was normally her greatest pride, for he was a youth of some versatility and could, it was claimed, speak English. This was true enough, in a way. But although his voice was perfectly normal when talking Spanish, he spoke English in a faint, high-pitched, tinny whine which was well-nigh indecipherable. This mystified me at first, until I discovered that he had learnt his English from an antique pre-1920 gramophone and could only be said to be suffering from a good ear.

But this dentist was devoted to Lola, and spent most of the hours of courtship in his surgery gazing into her mouth. They thus enjoyed a unique, almost speechless intimacy. Yet tonight, when he arrived, Lola blazed with fire and fury and would have nothing to do with him. For a while he did card tricks, to try to curry favour, but no one took any notice. Meanwhile the aunt entertained by dancing, dressing up and singing down the telephones. But still Lola's great eyes glowered above the feast. The aunt wrung her hands in dismay and brought more pork, even photographs of her dead relations. Until the dentist, grown 
desperate at last, threw down his cards and produced from his pocket a plaster cast of Lola's teeth. "Here you are," he said, blushing angrily. "I had meant to give it to you for Christmas."

But all was now well. Everyone exclaimed with admiration, and Lola took his arm. laughing deep in her throat, and would not leave his side again for the rest of the evening.'

Another kind of lover was introduced by John Osborne. ${ }^{20}$ 'Pamela went on holiday to Switzerland with the dentist from Derby. Not only was he rich, a member of the Theatre Committee, but, before going to work on my teeth, had, it seemed, made me the town cuckold. Only sphinxes conceal such banal secrets. Dentistry was not then a profession that provoked much gratitude and the events had a logic of sorts.

\section{The mariner!}

Osbert Sitwell attributed a maritime predeliction to dentists. ${ }^{21}$ 'I have always been interested in the predispositional factors that induce a man to adopt any particular profession, and I believe very often, whatever the trade, from dentist to dustman, you will find a sense of vocation has been the chief cause...

Among the various data I can offer, without any attempt at deduction therefrom, is the curiously inconsequential fact that enquiries usually elicit that members of the dental profession originally wished to join the Navy, but were prevented by one reason or another; and that they are apt to retain a great devotion to the sea and sailing.'

\section{The lady dentist}

In literature all dentists are men, with two exceptions who seem to fare better in the popularity stakes than most of their male colleagues. Alain Robbe Grillet evoked their gentle touch. ${ }^{22}$ 'I remember the close woman friend with whom my mother must have been in love (or vice versa) who was a dental surgeon in Brest. She always looked after our teeth when we were children and her gentleness and skill added to the charm of her - to us - very luxurious flat, where she played "The submerged cathedral" on an ebony grand piano. It is she who told me about the strange wound that Henri de Corinthe had on his neck: two little red holes about a centime- tre apart that she found when she was taking out a wisdom tooth.'

Wilfred Taylor was full of praise for a young female graduate. ${ }^{23}$ 'The nicest tooth extraction I ever had in my life took place in Thurso, Caithness when I was about nineteen years old. I have had a lot of teeth pulled in my time, and I can remember most of the occasions but none with more affection than that morning of blessed relief in Thurso....

I was feeling completely at peace with the world when the toothache struck me. I had been having supper with Lloyd and his parents and two real cousins of Lloyd's who had just completed their dental studies at Edinburgh University. Lloyd's father was a solicitor who was an eager student of English county cricket. The Times didn't reach Thurso until the evening of the following day and we used to read the scores avidly in Lloyd's house after supper while we drank our coffee. At the time I was a devoted aficionado of Nottinghamshire while the Galloway family distributed their admiration between Surrey and Yorkshire.

Not even a notable victory by Notts, could assuage my torment that night. The pain was so fiendish that I got out of bed and went to see Lloyd's cousins who were still up, playing cards. Fully fledged dentists though they were they treated my agony lightly and told me that they were on holiday and without equipment. They callously told me to see the local dentist in the morning.

I passed a terrible night of writhing and groaning. Nothing would kill the pain. At nine o'clock, exhausted and half demented, I presented myself at the local dentist's house. An attractive young girl showed me in and offered me a wooden chair in the kitchen. I must see the dentist at once, I told her. She explained that she was the dentist, or rather, acting as locum for the dentist who was on holiday. She didn't look like a dentist, and it turned out that she had just qualified, too. It was her first job.

I pointed out the aching tooth to her. She immediately diagnosed a bad abscess. It would have to come out, but in the circumstances, she couldn't give me a local anaesthetic. I told her that she would have to and implored her to take me into the surgery at once. I was in the surgery she said. I groaned. This wonderful girl then said she would com- promise and give me a half portion of anaesthetic. She did so and then proceeded gently and painlessly to extract the tooth. I was overwhelmed with joy and relief. In the midst of my euphoria I collected my wits and asked her what the fee would be for her professional services. 'One and ninepence,' she said, and I almost fainted.

I have had many a tooth pulled since that morning of glorious release in Caithness but never again have I experienced such a feeling of blessed relief on walking out of a dentist's surgery. As I recollect it I immediately began to make plans to have another bout of toothache. There was nothing morbid in this - just a simple yearning to undergo painless extractions at the hands of an attractive young lady at the cost of one and ninepence.

What I certainly did do was to boast of my dental discovery to Lloyd's two cousins who had been of no help at all to me in my agony and anguish. Proudly I exhibited to them my one and ninepenny gap and loudly sang the praises of the girl dentist who had succoured me so mercifully. Their interest was aroused and it turned out that the dentist was a classmate of theirs. After that I believe they spent a lot of time in her surgery and they had the grace to acknowledge that my tributes were not misdirected?

Many more dental characters described in too much detail for inclusion in this paper are well worth getting to know. The 'cheap American dentist', Warner, in George Orwell's ${ }^{24}$ 'Coming up for air', Valentine, the 'five shilling dentist' in G B Shaw's ${ }^{25}$ 'You Never Can Tell', the dentist at Monteriano in E M Forester's ${ }^{26}$ 'Where Angels fear to tread', Mr Pollfax in V S Pritchett's ${ }^{27}$ short story 'Oedipus Rex', Mr Tench in Graham Greene's 28 'The Power and the Glory', Con Boland in A J Cronin's ${ }^{29}$ 'The Citadel', Mr Gibbons in Richard Strachey's ${ }^{30}$ autobiography 'A Strachey Child', Mr Fitch in Lucy M Boston's ${ }^{31}$ 'Perverse and Foolish', Haxby in Peter de Vries's ${ }^{32}$ 'Reuben Reuben', Hector McDarroch, Mr Grover and The Butcher in James Herriott's ${ }^{33}$ 'All Things Wise and Wonderful' and Ernie and others in John Updike's ${ }^{34}$ 'Self-Consciousness'.

Few of these dentists endeared themselves to their patients but we should take comfort from the fact that the majority 
belong to a bygone age and we might expect our image to improve in proportion to advances in technology and pain control.

1 Mitchison N. All Change Here. London: Bodley Head, 1975.

2 Lewis C S. Surprised by Joy. London: Geoffry Bles, 1955.

3 Connolly C. Enemies of Promise. London: André Deutsch, 1938.

4 Bowles P. Without Stopping. London: Peter Owen Ltd, 1972.

5 Atwood M. The Edible Woman. London: Bloomsbury, 1979.

6 Christie A. Death in the clouds. London: Collins, 1973

7 Lehman R. A Swan in the Evening. London: Collins, 1967.

8 Asquith C. Haply I May Remember. London: James Barrie, 1950.

9 Greene J. The Greene Paradise. London: Marion Boyars, 1993.

10 James H. A Small Boy and Others. London: Macmillan and Co Ltd, 1913.
11 Partridge F. A Pacifists War. London: Hogarth Press, 1978.

12 Cooper D. Autobiography. Wilton, Salisbury: Michael Russell, 1971.

13 Raverat G. Period Piece. London: Faber and Faber, 1952.

14 Carrington D. Letters and Extracts from her Dairies. London : Jonathan Cape, 1970.

15 Cary J. Herself Surprised. London: Michael Joseph, 1941.

16 Powys J C. Autobiography. Syracuse: Colgate University Press, 1984.

17 Nabakov V. Lolita. London: Weidenfeld and Nicholson, 1955.

18 Saroyan W. Here comes there goes you know who. London: Peter Davies, 1962.

19 Lee L. A Rose for winter. Middlesex: Penguin, 1955.

20 John Osborne. A Better class of person. London: Faber and Faber, 1981.

21 Sitwell O. Great Morning. London: Macmillan, 1949.

22 Robbe Grillet A. Ghosts in the Mirror. London: John Calder, 1988.
23 Taylor W. Scot Easy. London: Max Reinhardt 1955.

24 Orwell G. Coming up for air. London: Victor Gollanz, 1939.

25 Shaw G B. You never Can tell. London: Odhams Press, 1897.

26 Forster E M. Where angels fear to tread. London: Edward Arnold, 1905.

27 Prichett V S. Oedipus Rex. Oxford Book of Short Stories. Oxford: University Press, 1988.

28 Greene G. The Power and the Glory. London: Bodley Head, 1940.

29 Cronin A J. The Citadel. London: Victor Gollanz Ltd, 1937.

30 Strachey R. A Strachey Child. Oxford: Simonette Strachey, 1979.

31 Boston L M. Perverse and foolish. Cambridge: Colt Books, 1979.

32 De Vries P. Reuben Reuben. London: Victor Gollancz, 1965.

33 Herriot J. All things wise and wonderful. London: Michael Joseph, 1978.

34 Updike J. Self-Consciousness. London: André Deutsch, 1989. 